\title{
ОСОБЛИВОСТІ ФУНКЦІОНАЛЬНОЇ ХАРАКТЕРИСТИКИ ХВОРИХ НА ІНФАРКТ МІОКАРДА З СУПУТНЬОЮ ПАТОЛОГІЕЮ ПЕРИФЕРИЧНИХ АРТЕРІЙ ТА ЇХ ГОТОВНІСТЬ ДО РЕАБІЛІТАЦІї
}

\author{
Левицька Л. В., к. мед. н. \\ Україна, м. Тернопіль, Тернопільський державний медичний університет \\ імені І. Я. Горбачевського
}

DOI: https://doi.org/ 10.31435/rsglobal_ws/30122018/6266

\section{ARTICLE INFO \\ Received: 08 October 2018 \\ Accepted: 18 December 2018 \\ Published: 30 December 2018 \\ KEYWORDS \\ Cardiac rehabilitation, myocardial infarction, peripheral arteries comorbidity, Charleson Comorbidity Index.}

\begin{abstract}
Effective rehabilitation of patients with myocardial infarction (MI) and peripheral arteries comorbidity (PAC) requires special assessment of functional status and cardiovascular reserves among patients with this disease. The purpose of the given research was to analyze the relationship of peripheral vascular comorbidity with functional characteristics of patients with myocardial infarction.

The reliability of the direct relationship between the presence of PAC in patients with myocardial infarction and the incidence of left ventricular aneurysm and mortality, direct correlation between the presence of PAC and the levels of systolic and diastolic blood pressure, as well as between the presence of the PAC and the Charlson Comorbidity Index, was established. The results of high contingency between the MI, the presence of PAC and its complications indicate the common pathogenetic mechanisms of development and progression of these conditions and the need to consider the presence of peripheral vascular pathology in the development of an individualized rehabilitation program for such patients. The Charleson Comorbidity Index can serve as a means for quantitative assessment of comorbidity degree in patients with $\mathrm{MI}$ and PAC.
\end{abstract}

Citation: Левицька Л. В. (2018) Osoblyvosti Funktsionalnoi Kharakterystyky Khvorykh na Infarkt Miokarda z Suputnoiu Patolohiieiu Peryferychnykh Arterii ta Yikh Hotovnist do Reabilitatsii. World Science. 12(40), Vol.1. doi: 10.31435/rsglobal_ws/30122018/6266

Copyright: (C) 2018 Левицька Л. В. This is an open-access article distributed under the terms of the Creative Commons Attribution License (CC BY). The use, distribution or reproduction in other forums is permitted, provided the original author(s) or licensor are credited and that the original publication in this journal is cited, in accordance with accepted academic practice. No use, distribution or reproduction is permitted which does not comply with these terms.

Вступ. Висока поширеність кардіологічних захворювань і їх часте поєднання 3 різними коморбідними станами спричиняють ріст кількості пацієнтів, у яких лікувальні підходи виходять за рамки загальноприйнятих стандартів. Мультиморбідність значно ускладнює процес діагностики i лікування, збільшує число ускладнень, сприяє зростанню частоти і тривалості госпіталізації, ранньої інвалідизації пацієнтів, а також перешкоджає проведенню реабілітаційних заходів в повному обсязі. У спеціальній літературі також недостатньо висвітлено проблему особливостей оцінки функціонального стану хворих на інфаркт міокарда (IM) в поєднанні 3 коморбідною патологією, не розроблено адекватних програм реабілітації для таких пацієнтів [1-3].

Поширеність захворювань периферичних судин (ЗПА) зростає у всьому світ, причому пацієнти із ЗПА мають не тільки знижену якість життя, але й високий ризик серцево-судинних подій, таких як інсульт, інфаркт міокарда і смерть. Результати досліджень останніх років свідчать про збільшення випадків ЗПА, особливо термінальних стадій, 3 критичною ішемією кінцівок. До 
прикладу, загальна кількість ампутацій ішемізованих кінцівок в Німеччині залишається високою (> 50000 / рік), проте загальні темпи великих ампутацій постійно зменшуються (- 31\% з 2005 по 2014 роки). На відміну від частоти проведення великих ампутацій, серцево-судинна та загальна смертність у таких хворих залишається високою і майже не змінюється порівняно 3 історичними даними. Причини для відсутності поліпшення прогнозу у хворих на ЗПА залишаються неясними [4,5].

Мета дослідження - аналіз взаємозв'язку коморбідної патології периферичних артерій (КППА) з функціональними показниками у хворих на інфаркт міокарда.

Матеріал і методи дослідження. Обстежено 371 хворого на гострий інфаркт міокарда, які проходили стаціонарний період реабілітації в кардіологічному відділенні Тернопільської університетської лікарні. Діагностику, лікування та реабілітацію пацієнтів проводили згідно чинних протоколів [6-9]. Критеріями включення в дослідження були підтверджений діагноз гострого IM і письмова інформована згода пацієнтів на участь в дослідженні. Критерії виключення: наявність гемодинамічно значущих вад серця, психічні захворювання та захворювання внутрішніх органів в стадії декомпенсації. Вік пацієнтів становив 66,16 $\pm 10,41$ років. Серед обстежених було 249 (67,12\%) чоловіків і 122 жінки (32,88\%).

Параметри внутрішньосерцевої гемодинаміки визначали, оцінюючи ехокардіоскопічні показники, виміряні на аппараті Philips HD11XE, електрокардиографічні показники серцевої діяльності вивчали за допомогою ЕКГ аппарата «ЮТАС», біохімічні показники крові визначали загальноприйнятими методами, використовуючи стандартні тестові системи (Пліва - Лахема, Чехія).

Статистична обробка результатів досліджень здійснювалась за допомогою стандартних алгоритмів варіаційної статистики, для розрахунків використовувалась комп'ютерна програма Excel (Microsoft Office, USA), iз використанням кореляційного аналізу. Для оцінки достовірності різниці абсолютних значень середніх величин розраховували t-критерій Стьюдента або критерій $\chi 2$ (різниця вважалась достовірною при $\mathrm{p}<0,05$ ). Взаємозв'язок двох ознак вивчали методом кореляційного аналізу за Пірсоном (r), зв'язок (асоціацію) двох якісних ознак оцінювали за допомогою коефіцієнтів асоціації i/або контингенції, якісної та кількісної ознак - за допомогою точково-бісерійного коефіцієнта кореляції [10].

Результати та їх обговорення. При вивченні зв'язків між наявністю артеріальної периферичної судинної патології та категорійними показниками функціонального стану організму і частотою ускладнень IM було виявлено 2 вагомих залежності: достовірність прямого зв'язку між наявністю коморбідної судинної патології і смертністю, а також між наявністю судинної патології і частотою розвитку аневризми лівого шлуночка. Тобто, в досліджуваній когорті хворих на IM з КППА аневризма лівого шлуночка і смертність достовірно більш поширені, ніж серед осіб без патології периферичних артерій (табл. 1).

Таблиця 1. Результати дослідження взаємозв'язків функціональних категорійних показників у хворих на інфаркт міокарда в поєднанні з коморбідною патологією периферичних артерій

\begin{tabular}{|c|c|c|c|c|c|}
\hline Показник & $\begin{array}{c}\text { Кількість хворих } \\
\text { на ІМ з КППА }\end{array}$ & $\begin{array}{l}\text { Кількість хворих } \\
\text { на ІМ без КППА }\end{array}$ & $\begin{array}{l}\text { Коефіцієнти } \\
\text { асоціації }\end{array}$ & $\chi^{2}$ & $\mathrm{P}$ \\
\hline 1 & 2 & 3 & 4 & 5 & 6 \\
\hline Чоловіки & 55 & 194 & \multirow{2}{*}{$-0,211$} & \multirow[t]{2}{*}{2,981} & \multirow[t]{2}{*}{$\overline{0,084}$} \\
\hline Жінки & 37 & 85 & & & \\
\hline $\begin{array}{l}\text { Парокизм фібриляції } \\
\text { передсердь }\end{array}$ & 15 & 33 & \multirow[t]{2}{*}{0,184} & \multirow[t]{2}{*}{1,231} & \multirow[t]{2}{*}{0,267} \\
\hline $\begin{array}{l}\text { Відсутність } \\
\text { пароксизму фібриляції } \\
\text { передсердь }\end{array}$ & 77 & 246 & & & \\
\hline $\begin{array}{l}\text { Хронічна фібриляція } \\
\text { передсердь }\end{array}$ & 8 & 26 & \multirow[t]{2}{*}{$-0,04$} & \multirow[t]{2}{*}{0,036} & \multirow[t]{2}{*}{0,85} \\
\hline $\begin{array}{l}\text { Відсутність хронічної } \\
\text { фібриляції передсердь }\end{array}$ & 84 & 252 & & & \\
\hline $\begin{array}{l}\text { Атріовентрикулярна } \\
\text { блокада II-III ст }\end{array}$ & 7 & 13 & \multirow[t]{2}{*}{0,255} & \multirow[t]{2}{*}{1,18} & \multirow[t]{2}{*}{0,277} \\
\hline $\begin{array}{l}\text { Відсутність атріо- } \\
\text { вентрикулярної } \\
\text { блокади блокади II- III } \\
\text { ст. }\end{array}$ & 85 & 266 & & & \\
\hline
\end{tabular}


Продовження таблиці 1

\begin{tabular}{|c|c|c|c|c|c|}
\hline 1 & 2 & 3 & 4 & 5 & 6 \\
\hline Серцева астма & 23 & 53 & \multirow[b]{2}{*}{0,174} & \multirow[t]{2}{*}{1,531} & \multirow[t]{2}{*}{0,216} \\
\hline $\begin{array}{l}\text { Відсутність серцевої } \\
\text { астми }\end{array}$ & 69 & 226 & & & \\
\hline Набряк легень & 7 & 15 & \multirow[b]{2}{*}{0,183} & \multirow[t]{2}{*}{0,618} & \multirow[t]{2}{*}{0,432} \\
\hline $\begin{array}{l}\text { Відсутність набряку } \\
\text { легень }\end{array}$ & 85 & 264 & & & \\
\hline $\begin{array}{l}\text { Аритмії } \\
\text { надшлуночкові }\end{array}$ & 19 & 66 & \multirow[t]{2}{*}{$-0,087$} & \multirow[t]{2}{*}{0,353} & \multirow[t]{2}{*}{0,552} \\
\hline $\begin{array}{l}\text { Відсутність } \\
\text { надшлуночкових } \\
\text { аритмій }\end{array}$ & 73 & 213 & & & \\
\hline Аритмії шлуночкові & 15 & 43 & \multirow[b]{2}{*}{0,033} & \multirow[t]{2}{*}{0,042} & \multirow[t]{2}{*}{0,838} \\
\hline $\begin{array}{l}\text { Відсутність } \\
\text { шлуночкуових аритмій }\end{array}$ & 77 & 236 & & & \\
\hline Блокади & 24 & 67 & \multirow[b]{2}{*}{0,055} & \multirow[t]{2}{*}{0,161} & \multirow[t]{2}{*}{0,689} \\
\hline Відсутність блокад & 68 & 212 & & & \\
\hline $\begin{array}{l}\text { Аневризма лівого } \\
\text { шлуночка }\end{array}$ & 32 & 60 & \multirow{2}{*}{0,321} & \multirow[t]{2}{*}{6,54} & \multirow[t]{2}{*}{0,011} \\
\hline $\begin{array}{l}\text { Відсутність аневризми } \\
\text { лівого шлуночка }\end{array}$ & 60 & 219 & & & \\
\hline С-м Дреслера & 5 & 9 & \multirow[b]{2}{*}{0,266} & \multirow[t]{2}{*}{0,93} & \multirow[t]{2}{*}{0,335} \\
\hline $\begin{array}{l}\text { Відсутність с-му } \\
\text { Дреслера }\end{array}$ & 87 & 270 & & & \\
\hline $\begin{array}{l}\text { Епістенотичний } \\
\text { перикардит }\end{array}$ & 17 & 65 & \multirow[t]{2}{*}{$-0,145$} & \multirow[t]{2}{*}{0,933} & \multirow[t]{2}{*}{0,334} \\
\hline $\begin{array}{l}\text { Відсутність } \\
\text { епістенотичного } \\
\text { перикардиту }\end{array}$ & 75 & 214 & & & \\
\hline Діастолічна дисфункція & 45 & 133 & \multirow[b]{2}{*}{0,03} & \multirow[t]{2}{*}{0,059} & \multirow[t]{2}{*}{0,808} \\
\hline $\begin{array}{l}\text { Відсутність діастолічної } \\
\text { дисфункції }\end{array}$ & 44 & 138 & & & \\
\hline Мітральна регургітація & 35 & 104 & \multirow[b]{2}{*}{0,022} & \multirow[t]{2}{*}{0,032} & \multirow[t]{2}{*}{0,857} \\
\hline $\begin{array}{l}\text { Відсутність мітральної } \\
\text { регургітації }\end{array}$ & 56 & 174 & & & \\
\hline $\begin{array}{l}\text { Трикуспідальна } \\
\text { регургітація }\end{array}$ & 30 & 97 & \multirow[t]{2}{*}{$-0,049$} & \multirow[t]{2}{*}{0,143} & \multirow[t]{2}{*}{0,705} \\
\hline $\begin{array}{l}\text { Відсутність } \\
\text { трикуспідальної } \\
\text { регургітації }\end{array}$ & 61 & 179 & & & \\
\hline Помер & 8 & 10 & \multirow[b]{2}{*}{0,439} & 3,916 & 0,048 \\
\hline Виписаний & 84 & 269 & & & \\
\hline
\end{tabular}

Що стосується зв'язків між супутньою патологією периферичних артерій у хворих на IM i числовими функціональними показниками, - було зафіксовано пряму кореляцію між наявністю судинної патології і тривалістю анамнезу артеріальної гіпертензії, величиною систолічного та діастолічного артеріального тиску, товщиною стінок лівого шлуночка та розміром правого шлуночка, а також між наявністю судинної патології $\mathrm{i}$ індексом коморбідності (табл.2). Тобто, для осіб із інфарктом міокарда, який перебігає на фоні КППА, тривала артеріальна гіпертензія з високими показниками як систолічного, так і діастолічного артеріального тиску приводить до структурних змін міокарда, що, в свою чергу, поглиблює системні гемодинамічні порушення, сприяє розвитку та поглибленню судинної патології. 
Таблиця 2. Взаємозв'язки функціональних числових показників у хворих на IM iз коморбідною патологією периферичних артерій

\begin{tabular}{|c|c|c|c|c|c|c|c|c|}
\hline Показник & $\begin{array}{l}\text { Середнє } \\
\text { для осіб } \\
\text { із КППА }\end{array}$ & $\begin{array}{c}\text { Середнє для } \\
\text { осіб без } \\
\text { КППА }\end{array}$ & $\begin{array}{l}\text { Стандартне } \\
\text { відхилення }\end{array}$ & $\begin{array}{l}\text { Частка } \\
\text { осіб із } \\
\text { КППА }\end{array}$ & $\begin{array}{l}\text { Частка } \\
\text { осіб без } \\
\text { КППА }\end{array}$ & $\begin{array}{c}\text { Точко- } \\
\text { вобісе- } \\
\text { рійна } \\
\text { кореля- } \\
\text { ція }\end{array}$ & $t^{2}$ & $\mathrm{P}$ \\
\hline Вік, роки & 67,511 & 65,717 & 10,407 & 0,248 & 0,752 & 0,075 & 2,062 & 0,152 \\
\hline $\begin{array}{l}\text { Куріння, } \\
\text { років }\end{array}$ & 1,97 & 4,074 & 9,706 & 0,262 & 0,738 & $-0,096$ & 2,336 & 0,128 \\
\hline $\begin{array}{l}\text { Добова к-ть } \\
\text { сигарет, шт. }\end{array}$ & 2,239 & 2,926 & 7,741 & 0,262 & 0,738 & $-0,039$ & 0,389 & 0,533 \\
\hline $\begin{array}{l}\text { Тривалість } \\
\text { анамнезу АГ, } \\
\text { роки }\end{array}$ & 14,04 & 10,902 & 7,668 & 0,302 & 0,698 & 0,188 & 9,05 & 0,003 \\
\hline ЧДР/хв. & 20,859 & 20,167 & 3,505 & 0,251 & 0,749 & 0,086 & 2,695 & 0,102 \\
\hline $\begin{array}{l}\text { ЧСС в } \\
\text { гострому } \\
\text { періоді IM, } \\
\text { уд/хв. }\end{array}$ & 84,587 & 84,369 & 25,733 & 0,248 & 0,752 & 0,004 & 0,005 & 0,944 \\
\hline $\begin{array}{l}\text { САТ в } \\
\text { гострому } \\
\text { періоді IM, } \\
\text { мм рт. ст. }\end{array}$ & 143,91 & 130,18 & 30,174 & 0,248 & 0,752 & 0,197 & 14,878 & $\begin{array}{c}<0,000 \\
1\end{array}$ \\
\hline $\begin{array}{l}\text { ДАТ в } \\
\text { гострому } \\
\text { періоді IM, } \\
\text { мм рт. ст. }\end{array}$ & 87,446 & 80,466 & 15,874 & 0,248 & 0,752 & 0,19 & 13,84 & $<0,001$ \\
\hline $\mathrm{SpO}_{2,} \%$ & 93,864 & 94,418 & 4,092 & 0,253 & 0,747 & $-0,059$ & 1,11 & 0,293 \\
\hline $\begin{array}{l}\text { Товщина } \\
\text { задньої стінки } \\
\text { ЛШ, см }\end{array}$ & 1,15 & 1,107 & 0,159 & 0,241 & 0,759 & 0,117 & 4,165 & 0,042 \\
\hline $\begin{array}{l}\text { Правий } \\
\text { шлуночок, см }\end{array}$ & 3,195 & 2,162 & 3,223 & 0,276 & 0,724 & 0,143 & 5,818 & 0,017 \\
\hline $\begin{array}{l}\text { Індекс } \\
\text { коморбідності }\end{array}$ & 5,132 & 4,383 & 1,829 & 0,248 & 0,752 & 0,177 & 11,919 & 0,001 \\
\hline
\end{tabular}

Примітка: КППА - коморбідна патологія периферичних артерій; АГ - артеріальна гіпертензія; ЧДР - частота дихальних рухів; ЧСС - частота серцевих скорочень; САТ систолічний артеріальний тиск; ДАТ - діастолічний артеріальний тиск; IM - інфаркт міокарда; ЛШ - лівий шлуночок; $\mathrm{SpO}_{2}$ - насиченість крові киснем.

Отримані результати повністю співпадають 3 даними інших досліджень щодо взаємообтяжуючого впливу різних форм IXC, в тому числі і інфаркту міокарда, та хвороби периферичних артерій $[4,11,12]$. В найбільшому метааналізі, в якому вивчали захворювання периферичних артерій та їхні наслідки після інфаркту міокарда у 28771 пацієнтів, що були учасниками досліджень в CAPRICORN, EPEHESUS, OPTIMAAL та VALIANT, проаналізовано поширеність захворювань периферичних артерій (ЗПА), а також зв'язок між наслідками ЗПА та серцево-судинних захворювань у осіб з систолічною дисфункцією лівого шлуночка і серцевою недостатністю після перенесеного гострого інфаркту міокарда [13]. В результаті було встановлено, що хвороба периферичних артерій була незалежним предиктором для всіх фатальних та нефатальних серцево-судинних подій, за винятком інсульту.

Доведено, що ЗПА $є$ незалежним предиктором гіршого функціонального стану у пацієнтів з IM внаслідок поглиблення структурно-функціональних змін серця, погіршення параметрів центральної та периферичної гемодинаміки через структурні зміни серця та периферичних судин, метаболічно-функціональних порушень у внутрішніх органах, що супроводжувались частішим розвитком ускладнень інфаркту міокарда. Ці пацієнти є важливою 
групою для індивідуального режиму реабілітаційних заходів, який потребує ретельного контролю артеріальної гіпертензії та показників внутрішньосерцевої гемодинаміки.

Отримані дані щодо високої контингенції між інфарктом міокарда, його ускладненнями та судинною патологією периферичної локалізації свідчать про їх тісні або спільні патогенетичні механізми розвитку і прогресування, а також необхідність враховувати наявність коморбідної патології периферичних судин у хворих на IM при призначенні таким пацієнтам індивідуалізованої програми реабілітації. Індекс коморбідності при цьому відображає ступінь системних змін, тому може виступати в якості інтегрального показника, який суттєво впливає на функціональний стан організму, а отже, може використовуватись для прогнозування переносимості (адекватності) реабілітаційних заходів у таких коморбідних хворих.

Висновки. 1. Асоціація інфаркту міокарда з коморбідною судинною патологією периферичних артерій $є$ незалежним предиктором гіршого функціонального стану організму у таких пацієнтів, частіше приводить до ускладнень IM, підвищує летальність, а тому потребує індивідуального режиму реабілітаційних заходів.

2. Індекс коморбідності Чарльсона може слугувати інструментом кількісної оцінки ступеня коморбідності у хворих на IM з КППА при визначенні функціонального статусу та плануванні реабілітації.

\section{ЛІТЕРАТУРА}

1. Щорічна доповідь про стан здоров'я населення, санітарно-епідемічну ситуацію та результати діяльності системи охорони здоров’я України. 2017 рік / МОЗ України. Київ, 2018. 516 с.

2. Nobili A., Garattini S., Mannucci P.M. (2011) Multiple diseases and polypharmacy in the elderly: challenges for the internist of the third millennium. J. Comorbidity, 1: 28-44.

3. Lower mortality and cardiovascular event rates in patients with latent autoimmune diabetes in adults (LADA) as compared with type 2 diabetes and insulin deficient diabetes: A Cohort Study of 4,368 Patients.Wod M, Thomsen RW, Pedersen L, Yderstraede KB, Beck-Nielsen H, Hojlund K. Diabetes Res Clin Pract. 2018 Mar 5. pii: S0168-8227(17)32005-3.

4. Roffi M, Radovanovic D, Iglesias JF, Eberli FR, Urban P, Pedrazzini GB at al. Multisite vascular disease in acute coronary syndromes: increased in-hospital mortality and no improvement over time. Eur Heart J Acute Cardiovasc Care. 2018 Dec 5:2048872618814708. doi:10.1177/2048872618814708.

5. Malyar N, Freisinger E, Reinecke H. Dtsch Med Wochenschr. 2018 Jun;143(11):766-770. doi: 10.1055/s0044-100859.

6. 2017 ESC Guidelines for the management of acute myocardial infarction in patients presenting with STsegment elevation: The Task Force for the management of acute myocardial infarction in patients presenting with ST-segment elevation of the European Society of Cardiology (ESC) / Borja Ibanez Stefan James Stefan Agewall at al. European Heart Journal, Volume 39, Issue 2, 7 January 2018, Pages 119-177, https://doi.org/10.1093/eurheartj/ehx393

7. 2015 ESC Guidelines for the management of acute coronary syndromes in patients presenting without persistent ST-segment elevation: Task Force for the Management of Acute Coronary Syndromes in Patients Presenting without Persistent ST-Segment Elevation of the European Society of Cardiology (ESC) / Marco Roffi, Carlo Patrono at al. European Heart Journal, Volume 37, Issue 3, 14 January 2016, Pages 267-315, https://doi.org/10.1093/eurheartj/ehv320

8. 2016 European guidelines on cardiovascular disease prevention in clinical practice. The sixth joint task force of the European Society of Cardiology and other societies on cardiovascular disease prevention in clinical practice (constituted by representatives of 10 societies and by invited experts). Developed with the special contribution of the European association for cardiovascular prevention \& rehabilitation (EACPR). Piepoli MF, Hoes AW, Agewall S, et al. Eur J Prev Cardiol. 2016;23:NP1-NP96.

9. 2017 ESC Guidelines on the Diagnosis and Treatment of Peripheral Arterial Diseases, in collaboration with the European Society for Vascular Surgery (ESVS): Document covering atherosclerotic disease of extracranial carotid and vertebral, mesenteric, renal, upper and lower extremity arteries. Victor Aboyans Jean-Baptiste Ricco Marie-Louise E L Bartelink Martin BjörckMarianne Brodmann Tina Cohnert at al. European Heart Journal, Volume 39, Issue 9, 1 March 2018, Pages 763-816,https://doi.org/10.1093/eurheartj/ehx095

10. Уткин В.А. Методические аспекты математико-статистического анализа медицинских данных Часть 2. Атрибутивная статистика в медицинских исследованиях/ Медицинский вестник Северного Кавказа, 2009; №3(15): С. 70-75.

11. Швед M.І., Левицька Л.В. Сучасні стратегії лікування та реабілітації хворих на інфаркт міокарда (Видання третє, доповнене). - Київ: Медкнига, 2015. - 148c.

12. Швед М.І., Левицька Л.В. Сучасні технології відновного лікування хворих із гострим коронарним синдромом. - Київ: Видавничий дім Медкнига, 2018. - 176 с.

13. Inglis SC, Bebchuk J, Al-Suhaim SA, Case J, Pfeffer MA, Solomon SD at al. Peripheral artery disease and outcomes after myocardial infarction: an individual-patient meta-analysis of 28,771 patients in CAPRICORN, EPEHESUS, OPTIMAAL and VALIANT. Int J Cardiol. 2013 Sep 30;168(2):1094-101. doi: 10.1016/j.ijcard.2012.11.033. 